\title{
Positioning the HIV/Aids Menace: Challenges for Marketing Communications Led Behavioural Change in Zimbabwe
}

\author{
Ernest M Kadembo \\ Department of Marketing, The Business School \\ University of Huddersfield, University Centre Oldham \\ Cromwell Street, Oldham, England, UK, OL1 1BB
}

Tel: 44-161-213-5049Ｅ-mail: e.m.kadembo@hud.ac.uk

\begin{abstract}
The medical sophistication of modern day has been rendered helpless in the face of HIV/AIDS. The incurable nature of the HIV/AIDS virus which changes its morphology is putting a huge strain on the various fronts of humanity. The economic and social devastation of the HIV/AIDS menace has meant that no progressive force on earth will not give this epidemic some attention. Zimbabwe is a developing country in Southern Africa which has been grappling with the menace whose spread has been largely due to ignorance and wanton denial of the devastating effects over the years. Multitudes of promotional programmes to change behaviour have met with mixed success. To this day 3000 people die weekly with calamitous effects to the nation. There has been a reduction in the numbers affected and part of the argument is that promotions for preventive behaviour is bearing fruit. This study seeks to evaluate successes and failures of various programmes in the fight against HIV/AIDS with particular emphasis on whether marketing communications to promote good behaviour has had any significant impact. It can be argued that this process does not render itself to marketing communications. On the contrary it does. The experts in the area of marketing point out that goods, services ideas, places or persons can represent a product. In this regard the product is the idea of behavioural change. The direct benefit from the idea is to serve the human race from extinction. This paper will argue that it can be done, it can bear fruit, but it is a mammoth task and calls for collective and individual responsibility across the private, public, religious groupings, the donor community etc. It is the contention of this paper that the idea of changing behaviour in the fight against HIV/AIDS has to be sold to society and this paper argues that marketing communications can make a huge difference in serving millions of human lives. Ultimately the perception people have of HIV/AIDS will determine how they position it it vis-à-vis life.
\end{abstract}

Keywords: Health Crisis, HIV/AIDS, Behaviour Change, Perception and Positioning, Marketing Communications

\section{Introduction}

The World Health Organisation report on HIV/AIDS of May 2006 quotes UNFPA Executive Director, Thoraya Ahmed Obaid, (http://www.who.int/hiv/mediacentre/news60/en/index.html, Accessed 6.11.06) "Prevention remains our first and most effective line of defence."

This statement strikes on the core of the HIV/AIS crisis the world is facing; put simply it is an incurable mass killer. It calls for behavioural change against rock old practices at the heart of human existence, that is, sex and medical practices in both the scientific and traditional medication which often include blood exchange or cutting or piercing the body one way or the other. Suffering from HIV/AIDS at the moment leaves the human race with only one definitive tool for prevention of contraction but not abstinence from the act of sex as that is an attempt to evade reality. The complication in this quagmire is that some religious sects would argue that the only way to avoid HIV/Aids is abstinence from sexual activities. This works perfectly but is unrealistic given the natural human desires for sex despite claims from quotas of society which have been shocked by their membership's HIV/Aids status.

Taylor (1997: 43) cited in Fourie and de Jager (2001: p 94) state:-

In the last two decades, the HIV (Human Immunodeficiency Virus) that causes AIDS (Acquired Immunodeficiency Syndrome), has spread swiftly and silently throughout the world profoundly affecting the lives of men and women, their families, business and societies.

This is the core of the problem that this paper seeks to engage from an influence perspective, ie., communications as a behavioural change tool. To the extent that HIV/AIDS has impacted lives with devastating effects makes it an enemy of humanity and needs to be engaged head on. To the extent that there is no known cure makes it complicated for health institutions in all spheres - public or private. Fourie and de Jager (2001) further present a teething question about the 
incurable nature of HIV/AIDS making reference to the potential it has to destroy mankind, stating the old adage "prevention is better than cure". However, there are human practices that are at the core of human existence like the notion of sex and its related secrecy stigmas in societies like the developing world. In that respect the change of behaviour is paramount but complicated. It can be argued ultimately that the failure to contain the disease is a failure of communication. It is the need to change behaviour and survive or contain the menace of HIV/AIDS which underpin this study.

The tool to employ in the communication to fight HIV/AIDS O'Shaughnessy (1996: p 55) argues that "With greater certainty we can say that, although there is an element of substitutability, some social persuasion contexts favour the marketing approach and others would be better suited to propaganda." To the same end O'Shaughnessy (1996) argues that propaganda was originally defined as the dissemination of biased ideas and opinions usually aided by the use of lies and deception.

\subsection{Study Objective}

Debates in academic circles, the medical, political and economic fraternity are largely a reaction to a crisis in the face of this devastating plague. In view of the multitudes of deaths, economic, industry and family disintegration there are concerns in every sphere of life for the need to deal with the HIV/AIDS menace. Adding the live debate on the best way to combat the menace created by the HIV/AIDS epidemic this study will seek to meet the following objectives:-

- Discuss the nature of HIV/AIDS, its impact on the different aspects of life and how behaviour change can be realised through marketing communications.

- Highlight the global impact of HIV/AIDS as projected by the various health institutions the world over

- Profile Zimbabwe's fight against HIV/AIDS in respect of the process and impact of the various programmes the country has embarked on

- Discuss the effects of the HIV/AIDS menace has had on the various aspects of business, society and families.

- Assess the impact of marketing communications in positioning the AIDS menace in the minds of the population of Zimbabwe.

- Project behavioural tendencies of Zimbabweans five years from now given the AIDS epidemic

In carrying out this study the author is aware of the need to be focused given the differences in behaviour. Obviously, there is need to take into account the fact that the study has to be culturally appropriate and that stage-specific strategies are urgently needed if the fight against HIV/AIDS was to be successful (Normal and Carr, 2003).

\section{The HIV/AIDS Phenomenon}

Shaluf et al (2003: 29) states that "a crisis is an abnormal situation which presents extraordinary, high risk to business..." In the case of HIV/AIDS the situation is a calamity of unequalled proportions. The human race has not faced a menace of this magnitude in recent times. The HIV/AIDS menace adversely affects every human process-health funding, productivity in industry, family bonding in the face of multitudes orphans, shortening life spans etc. The contention of this paper is that the HIV/AIDS epidemic calls for more cooperation by all progressive forces without which the calamity will continue and everybody will be at risk with or without changing behaviour.

The enormity of the HIV/ AIDS menace is best epitomised in a World Health Organisation report of May 2006 (http://www.who.int/hiv/mediacentre/news60/en/index.html, Accessed 6.11.06) which states:-

- An estimated 38.6 million [33.4 million - 46.0 million] living with HIV worldwide - 4.1 million [3.4 million - 6.2 million] newly infected in 2005 - 2.8 million [2.4 million to 3.3 million] died of AIDS in 2005

An estimated 38.6 million people are living with HIV worldwide. Approximately 4.1 million people became newly infected with HIV, while approximately 2.8 million people died of AIDS-related illnesses in 2005. While the epidemic's toll remains massive, experts find reasons for optimism, as well as guidance for how to improve the AIDS response. Sarah Tikiwa (2006) reporting for the Sundaymail in Zimbabwe states that, "Since the first cases of acquired immunodeficiency syndrome (Aids) were reported in 1981, infection with the human immunodeficiency virus (HIV) has grown to pandemic proportions, resulting in an estimated 65 million infections and 25 million deaths.”

These figures paint a bleak picture about the menace created by the epidemic which threatens the long term sustenance of the human race. The situation is further complicated by the non-discriminatory nature of the epidemic. The HIV/Aids epidemic knows no age, race, wealth, location or any other differentiating factor for which it can spare humanity. Panic about the epidemic cuts across all human groups whatever the differentiating factor. The epidemic has revealed hidden practices where some cultures, religious groups or other values that have been communicated as either absolving or simply very strict on sexual acts have been victims of the epidemic. Men of the collar purported to observe celibacy have been victims to the amazement of their followers and some religions sects where acts of sex before marriage or 
adultery are punishable by death have found cases of HIV/Aids increasing amongst their membership. This development is a true reality check against an act of humanity which is at the core of humanity.

\section{Selling the Idea of Behaviour Change through Marketing Communications}

For people to understand the importance of behavioural change in the fight against Aids there has to be an effort to sell the whole idea in a marketing sense. The people would always ask questions about the value of changing their behaviour especially given the various misconceptions of what Aids is all about.

According to Bathie and Sarker (2002: p241) put forward factors required in the realisation of a marketing orientation as:-

- Recognise that organisational objectives are only achieved through exchanges with customers

- Recognise the primacy of customers in the exchange process

- Organise organisational activities around a focus on customers receiving value for exchange with the organisation

- Create an exchange relationship with customers that are mutually beneficial as a basis for continued relationships.

Bathie and Sarker (1996) further present a framework for the flow of value in marketing as illustrated in figure 1. The main point is that the focus has to be on what the customer needs. The first phase in the framework is understanding customer value requirements that is to suggest that organisational marketing activities should be driven by the value that the customers expect from their business process. It is important to note that in this respect it is critical that organisations consider customer value deployment which seeks to inculcate the voice of the customer in corporate processes. Subsequent to understanding value requirements the next phase is the creation of customer value, then communicating value and ultimately delivering such value. In the case of HIV/AIDS the core of the message is that there is value in staying healthy the opposite is that contracting HIV/AIDS leads to a painful death. For families the pain of bereavement may mean children dying or being left orphaned and living very painful lives. The point is that ultimately engaging in unprotected sex or sexual promiscuity is a risky act.

Kates (2002) raises the role of community based organisations in providing therapy to people living with HIV/AIDS as he points out that this incorporates contemporary social conditions and historical conditions in both societal practice and marketing theory. The core of this argument lies on the understanding that people's conditions can improve because of the environment around them. Equally the perception of these organisations has a huge effect on the influence they can have on the community. Campbell (2004) puts across the case of peer education where she observes that processes that underpin successful peer education include first, an environment for peer identity, given that sexuality is shaped; second, sex education should empower young people to take ownership of sex negotiations with confidence in health information and intervention. Campbell further contents that young people's lives have been blighted by unemployment, lack of education which undermine their confidence to make decisions and that success in peer education programmes can be enhanced by appropriate community partnerships of the various forces in the community.

In a study focusing on change in relation to recycling behaviour Mee and Clewes (2004) observed that there was need for segmentation research if the process of developing specific communications and messages directed at different segments were to be effective. There are various groups of people whose HIV/Aids risk is different, thus necessitating a clear understanding of each group hence the need for research into the behaviour of such groups which may need to change in the fight against HIV/Aids. In their study on HIV-related behavioural change in Trinidad and Tobago, Norman and Carr (2003) make a very important claim that a strong knowledge base about HIV transmission could promote protective behaviours which could minimise the menace of HIV/Aids to people at both secondary and primary levels of transmission. This would also reduce the transmission of other sexually transmitted infections.

Makin and Sutherland (1994) observed that individuals behave the way they do because of internal factors (as personality traits, attitudes, and moods) or external factors as culture, pressure associations etc). In the case of the spread of HIV/AIDS there are both internal and external factors at play. The human desire for sex being a biological process is internal to the individual. However, the promotion of sex in films and commerce certainly is external but has a huge effect on the proliferation of sex activities. The idea of sex holidays, entertainment etc which ultimately create an atmosphere for engaging in sex are products of marketing pleasure. Given that marketing has a significant contribution to the proliferation of sex one would argue that marketing can equally contribute to the reduction of sex if the marketing message seeks to do so. Scriven and Stevenson (1998) highlight that issues regarding psychological development refer principally to the intrapersonal dimension, ie, social influences, and are concerned with factors intrinsic to the individual. And that adolescent health-related behaviour is influenced by a multitude of variables, hence interventions designed to shift behaviour must both appreciate and target these multidimensional factors. 
The model by Norman and Carr (2003) figure 2 is of particular interest in that it brings to the fore the key variables of concern. Knowledge has not necessarily led to behavioural change for if this had been the case there might not have been as many who perished from the disease over the years. It would appear the real problem lies in denial. With people denying the menace it would appear there is deliberate sexual promiscuity on the pretext that there will be no effect. Apparently this was and will continue to be a clear death warrant. Protection is key in the fight against the menace. In the same vein the clergy have called on people to abstain. Without attempting to be blasphemous the author will argue that this phenomenon is on the core of human existence and it is virtually impossible to deny people engaging in sex, be it single or married and making it even more complicated is the incidence of same sex couples engaging in sexual activities. While the model presents an objective analysis of the variables dictating the spread of knowledge about the HIV/Aids phenomenon there is a problem in the human practices and believes about the practices incorporated in the model. The sexual practices in the community are largely secretive and essentially the task of educating the community becomes more complicated. It would appear the groups which are most at risk as prostitutes and men mostly associated with sexual promiscuity are more amenable to talk about the menace openly than groups that are not normally associated with sexual promiscuity. The bulk of the Zimbabwean population lives on the rural side where there is limited access the more reliable means of mass communication such as newspapers and the television. The use of condoms and their possession is often frowned upon in the community and that puts a strain on its usage. All these practices have been and continue to be tackled with the aid of marketing communications to change behaviour.

Sieg (2003) makes a case for sex education that it is of interest to society at large in view of HIV/AIDS and other sexually transmitted diseases and high teenage pregnancies, so that young people can develop appropriate attitudes and practices and make informed decisions about sexual practices.

Goodman (2006: p 197) argues that:

"A program in corporate communication...should focus on the strategic challenges that executives face:

- building trust;

- efficiency;

- building a culture of accountability;

- counselling the corporation and the CEO;

- managing the company reputation;

- managing the impact of globalization;

- transparency in media relations and reputation management;

- managing corporate citizenship and corporate social responsibility;

- managing issues and crises; and

- writing as the core skill for corporate communication;"

While the argument by Goodman is in respect of commercial operations the same is true in the public sector set up where the biggest challenge in the fight against HIV/AIDS lies. The public sector is often associated with red tape, lack of motivation and trust as most acts are mere political posturing. The practices of politicians adversely affect the image of public institutions hence the need for strong communications in the fight against HIV/AIDS.

The marketing communications process is carried out in a systematic manner and incorporates a number of steps as outlined by Rowley (1998: p 385)

- identify target audience;

- determine communication objectives;

- design the message;

- select communication channels;

- establish promotional budget;

- decide on promotional mix;

- measure results;

Marketing communications can yield results only if the communicator has a clear understanding of the audience and the meaning of symbols and words used in the message. Effective marketing communications will change consumer or human behaviour. In a study on whether the opinion leaders form a marketing communications segment Chaney (2001: p 307) concluded that "the statistical results indicate that opinion leaders are the magnetic core who can attract consumers' confidence. ... Influencing journalists ....is a viable indirect method of reaching the masses facilitated by 
opinion leaders." In this study the main social concern has been the denial and concealment of the HIV/AIDS status fearing community isolation because any disease acquired because of sexual promiscuity attracts social disapproval and hence the desire not to divulge the positive HIV/AIDS status.

Kotler and Kelly have advanced the argument on the new orientation about marketing which is embracing and have called the approach the holistic marketing approach as illustrated in figure 3. The important aspect of this approach is that it takes into consideration both the internal and external dynamics about the phenomenon of marketing.

While the holistic marketing approach's applications are largely focused on commercial activities it is equally important in non- commercial situations and its elements fit in with the challenges for tackling the HIV/Aids epidemic. From the holistic marketing approach there are potential applications to the process of fighting the HIV/Aids epidemic in the following manner:-

- Internal Marketing would apply to the employees of the National Aids Council which is the government unit that is tasked with fighting the epidemic. They will need to be supported so that they can do a good job.

- Integrated Marketing would be relevant to the extent that it requires the different government departments and the private sector to co-ordinate their efforts in changing the behaviour of the society. This is a complex relationship and often difficult to secure the appropriate cooperation.

- Relationship Marketing is extremely important because it would mean that the message is well received because the government would maintain good links with the different stakeholders, among them hospitals, businesses, society in general and non-governmental organisations.

- Social Responsibility in respect of the HIV/Aids epidemic would apply to all levels of engagement from the individual, private and public organisations. All institutions and individuals have an obligation to fight the menace through a multitude of programmes and individual behaviour and attitudes.

\section{HIV/AIDS Programmes in Zimbabwe}

In the Uniting the World against AIDS, UNAIDS, Fact sheet 2006 it is stated that:

"In southern Africa, HIV prevalence levels are exceptionally high (except for Angola-3.7\%). However, in Zimbabwe, where 1.7 million people are living with HIV, data have shown a decline in HIV prevalence which is currently estimated at $20.1 \%$, down from $22.1 \%$ in 2003. This decline is twofold; studies have shown both a substantial increase in condom use since the early 1990's and that more young people have been delaying their

sexual début and reducing the number of casual sexual partners; however, a significant factor in the decline is attributed to high-mortality rates."

While the figures provided by the UNAIDS report sound encouraging there is a dimension that has not been tackled in the discussion. A quarter of the Zimbabwean population has found its way out of the country to escape the crisis and which has afflicted the country since 1998. In the main the government of Zimbabwe has failed in a number of aspects that could have reduced the adverse effects of HIV/AIDS.

While these measures have had a positive impact, the Government's response to HIV and AIDS has ultimately been compromised by numerous other political and social crises that have dominated political attention and overshadowed the implementation of the national AIDS policy. The NAC has also been constrained by poor organisation and a lack of resources. The government should not be presented as innocent victims of inevitable problems, though; many of the struggles facing the country stem from their mistakes and failures. While political commitment towards fighting AIDS is apparent in Zimbabwe, the decisions made by Mugabe in dealing with other issues have led to a situation where the government is unable to adequately address the crisis. (http://www.avert.org/aids-zimbabwe.htm accessed 31.07.07.)

The Zimbabwe government policies which have attracted international condemnation have seen a substantial reduction of the resources available for fighting HIV-AIDS. Other countries in the African Development Community (SADC) receive US\$240 per capita and Zimbabwe receives only US\$14 per person for HIV and AIDS response programmes from international donors. http://www.zimbabwejournalists.com/story.php?art_id=2584\&cat=1 , accessed 14.07.07

The website http://www.avert.org/aids-zimbabwe.htm, accessed 08.12.07, points at some chilling scenarios about the crisis that the country faces in stating the following:-

"Put simply, people are dying of AIDS before they can starve to death" The situation in Zimbabwe is now so bad that:

- Between 2002 and 2006, the population is estimated to have decreased by four million people.

- Infant mortality has doubled since 1990.

- Average life expectancy for women, who are particularly affected by Zimbabwe's AIDS 


epidemic, is 34 - the lowest anywhere in the world. Officials from the World Health
Organisation have admitted that since this figure is based on data collected two years ago,
the real number may be as low as 30 .
Zimbabwe has a higher number of orphans, in proportion to its population, than any other
country in the world, according to UNICEF. Most of these cases are a result of parents
dying from AIDS.

The HIV/Aids programmes in Zimbabwe have been hampered by a multitude of problems. The government unit tasked with the implementation of the relevant programmes has been fraught with corrupt acts which have deprived the programmes of important funds. The donor community in Zimbabwe has been stifled by a government that has become internationally isolated because of fear of spreading the message of democracy. The Zimbabwean economy has been in free fall since 1998 and has plummeted to a level where the exchange rate to the UK pound fell from ZW $\$ 5: 1 £$ to ZW $\$ 10$ million : $1 £$. The general poor health and subsequent deterioration in the quality of life has contributed to the worsening of the situation. Despite the multitudes of problems the country faces the various efforts have seen a reduction in the spread of the disease as acknowledged by the World Health Organisation.

\subsection{The Scope of Social and Economic Losses in the HIV/AIDS menace}

The HIV/Aids epidemic is simply a disaster of multiple proportions impacting an array of human facets among them social, health and economics. The notion of the HIV/Aids catastrophe has adversely impacted the development of nations especially the developing world where the provision of health services was weak and with the advent of HIV/Aids that has meant a huge strain that has brought the system to breaking point or melt down. The cost of the HIV/Aids epidemic that has been exacerbated by the political crisis bedevilling the country can be summarised as follows:-

- $\quad 1.7$ million people are living with HIV, data have shown a decline in HIV prevalence which is currently estimated at $20.1 \%$, down from $22.1 \%$ in 2003 . The ripple effects of these figures include among other things reduced productivity in the workplace, the significant strain on the meagre resources for health by the government which were already limited.

- An estimated 38.6 million [33.4 million - 46.0 million] living with HIV worldwide - 4.1 million [3.4 million 6.2 million] newly infected in $2005-2.8$ million [2.4 million to 3.3 million] died of AIDS in 2005 . The losses Zimbabwe suffers do not only relate to the Zimbabwean population but also the global impact which is constraining productivity across the world.

- There are 340000 people living with HIV who needs ARVs but only 80000 are getting the life-prolonging drugs. According to official figures an average of 3000 people die of HIV-related illnesses every week in Zimbabwe although the number is thought to be much higher. http://www.zimbabwejournalists.com/story.php?art_id=2584\&cat=1, accessed 14.07.07

- "A total of 16499 deaths were registered at the Harare District Office of which 39 percent were people aged between 25 and 44.According to the 2005 council health department report, the number of deaths in Harare last year was lower than that of 2004 in which 17365 deaths were recorded." http://www.herald.co.zw/inside.aspx?sectid=9812\&cat=1 accessed 5.10.06

- "Suicides accounted for 112 deaths with 51 percent of the deaths occurring in the 25 to 44 age group. At least 35 percent of the suicides occurred in the 15 to 24 age group. "The two age groups accounted for 85,6 percent of all suicides. As in previous years the most common method of suicides were ingestion of organophosphates, hanging and chloroquine overdose," reads part of the report. Malaria killed 129 people with 70 of the deaths occurring in the 25 to 44 age group."

http://www.herald.co.zw/inside.aspx?sectid=9812\&cat=1, accessed 5.10.06

- It is reported that more than 600000 people are in need of anti-retroviral because of their HIV/Aids status but only 120000 are receiving it. That means that there is about 480000 people at risk of death imminently because of lack of drugs and that is a big dent to both the social welfare for children and for the economic productivity of the country.

\section{The Impact of Marketing Communications on Behavioural Change in Zimbabwe}

Behavioural change related communication has had a positive impact on the spread of Aids in Zimbabwe and other countries as pointed in the UNAIDS Report 2006:-

The report notes some positive trends in young peoples' sexual behaviours. It says data shows increased use of condoms, delay of sexual debut and fewer partners. This has resulted in declines in HIV prevalence among young people between 2000 and 2005 in a number of African countries, including Botswana, Kenya and Zimbabwe. 
(http://www.redbolivia.com/noticias/News\%20in\%20English/32880.html, Accessed 21.11.06)

Change in sexual behaviour in Zimbabwe has been difficult to achieve but ultimately sense has prevailed because of a range of things, among them, effective marketing communications. The following are some of the key developments and programmes that have helped in changing sexual practices in Zimbabwe:-

- It is a common experience for families to suffer HIV/AIDS related deaths which has made the society realise the importance of behavioural change because of the painful death and the reality of such death. Previously people would claim that they would not be affected as the disease was for those with weaker protective ancestral spirits.

- The government of Zimbabwe with the support of non-governmental organisations supported by the donor community has worked on a range of initiatives to bring home the calamity of the AIDS menace. The message has taken a variety of initiatives, among them informative advertisements, drama on national television, posters at hospitals. The programme had to be comprehensive given the potential for HIV/Aids to wipe out societies.

- Graveyards have filled up and new ones have been opened up for burial and that has sent chills down the spines of most Zimbabweans as evidence of the devastation of the AIDS menace. The common clique that "seeing is believing" has been observable in Zimbabwe. The sight of weak, thin and regretting friends or relatives waiting to die has led people to ask questions about the cost of sexual promiscuity and prompted them to consider their sexual practices in view of the possible consequences in case they contract the virus.

- The state of health for people with a full-blown HIV/AIDS condition is cause for concern as society tends to shun them and that has led people to think about the implications of being in that state.

- Promotional messages have helped people in take relevant informed precautionary measures to minimise the risk of contraction.

\section{Conclusions}

While efforts have been made at different levels across the country it is important to note that the spread of HIV/Aids is down to the individual behaviour - both the individual and the community at large change and arrest the devastation or perish in defiance. While in most cases the message has taken long to stick the reality of the matter is that the HIV/Aids phenomenon is a tragedy of the highest order. In the case of countries like Uganda, Zambia, Malawi, the Democratic Republic of Congo among others in Africa and the generality of the affected parts of the world the political climate hampered the spread of the promotional message and the distribution of the medicines was curtailed and allowed the situation to deteriorate into a catastrophe. The truth of the matter is that the HIV/Aids crisis cannot be left to chance and that the nations and the world at large face a big test in the protection of the human race and the sustenance of the human race. What is not debatable in this situation is the fact that without change there is peril driven by this epidemic and it is extremely important that action continues to be taken as the devastation of the disease continues to threaten not only humanity but the sustenance of livelihood given that the most affected proportion of the population is the most productive.

In the case of Zimbabwe it is clear that the message has been accepted rather gradually with a significant effect on the social and economic standing of the country. Apparently the political situation that has seen an economic meltdown has further exacerbated the catastrophe. In conclusion it can be argued that behavioural change is important in the fight against HIV/Aids. While in Zimbabwe significant efforts have been made in the quest to change behaviour towards practices and activities that are catalytic in the ad of the disease the corrupt behaviours, the economic meltdown and some retrogressive beliefs and practices have had an adverse effect in the fight against the epidemic.

The model by Norman and Carr (2003) is consistent with the situation prevailing in the case of Zimbabwe where knowledge drives subsequent programmes. The relevant variables about the spread of knowledge in the fight against HIV/Aids bring a number of challenges to the country and community at large. There are disagreements across the government, religious groups and social groups about the best way to redress the crisis. Some practices have been found not to work with some groups claiming abstinence from sexual activities have contracted the disease and ignorance about the means by which the disease spreads have also created unnecessary fears and unwarranted quarantining of the victims of HIV/Aids in society.

Ultimately the whole battle against the HIV/Aids menace comes down to the individual. The ordinary people need to be informed and health provisions should be improved to ensure appropriate medication where there is need. The idea of protection through avoidance and use of condoms are the two main means which can make a difference. From a marketing perspective the key is the promotion of positive behaviour that aids the reduction of the spread of the disease. In the main marketing communications to promote behavioural change is critical in the fight against HIV/Aids in Zimbabwe. While the efforts have met with mixed success the scope remains for continued efforts to make further reductions in the spread of HIV/Aids. 


\section{References}

Bathie, D. and Sarkar, J. (2002); Total quality marketing (TQMK)- a symbiosis, Management Audit Journal, Volume 17, No 5, pp 241- 244.

Campbell, C. (2004), Creating environments that support peer-education: experiences from HIV/AIDS prevention in South Africa, Health Education, Vol 104, No 4, pp 197 - 200.

Chaney, M. I.(2001) Opinion leaders as a segment for marketing communications; Marketing Intelligence \& Planning, Volume 19, No 5, pp $302-308$.

De Jager, J and De Fowrie W , 2001 Proceedings: Advancing Knowledge Development in African Business Conference: The Prevalence of HIV/AIDS in South Africa: A case study; International Academy of African Business Development, pp $94-100$.

Goodman, B.M.(2006), Corporate communication practice and pedagogy at the dawn of the new millennium; Corporate Communications: An International Journal; Vol. 11 No. 3, pp. 196-213

Kates, M.S. (2002), Aids and community- based organisations: the marketing of therapeutic discourse; European Journal of Marketing, Vol 36, No 5/6, pp $621-641$.

Makin, J. P. and Sutherland, J.V. (1994), Reducing accidents in the workplace by the use of the behavioural approach has a remarkable success rate; Leadership \& Organization Development Journal, Vol. 15 No. 5, pp. 5-10.

Mee, N. and Clewes, D. (2004), The influence of corporate communications on recycling behaviour; Corporate Communications; An International Journal, Vol. 9 No. 4, pp. 265-275.

Normal, R.L. and Carr, R. (2003), The role of HIV Knowledge on HIV-related behaviours; Health Education, Volume103, No 3, pp $145-155$.

O’Shaughnessy, N. (1996), Social propaganda and social marketing: a critical difference?, European Journal of Marketing, Vol 30, No10/11, pp $54-67$.

Rowley, J. (1998), Promotion and marketing communications in the information marketplace; Library Review, Vol 47, No 8, pp. 383-387

Scriven A and StevensonV (1998), Psychological development of young adolescents:

implications for health education practice; Health Education, No 3, pp. 89-94.

Sieg, E. (2003), Sex education and the young- some remaining dilemmas; Health Education, Volume 103 No 1 , pp 34 -40 .

Shaluf, I. M., Ahmadun I.F. and Said M.A. (2003), A review of a disaster and crisis; Disaster and Prevention Management, Volume 12, No 1, pp 24 -32.

\section{Electronic Sources}

World Health Organisation, HIV/AIDS Report, May 2006, http://www.who.int/hiv/mediacentre/news60/en/index.html, Accessed 6.11.06.

http://www.who.int/hiv/mediacentre/200605-FS_SubSaharanAfrica_en.pdf, Accessed 6.11.06.

http://www.sundaymail.co.zw/inside.aspx?sectid, accessed 31.12.06.

http://www.redbolivia.com/noticias/News\%20in\%20English/32880.html, Accessed 21.11.06.

http://www.avert.org/aids-zimbabwe.htm accessed 31.07.07.

http://www.zimbabwejournalists.com/story.php?art_id=2584\&cat=1, accessed14.07.07.

http://www.herald.co.zw/inside.aspx?sectid=9812\&cat=1, accessed 5.10.06.

http://www.zimbabwejournalists.com/story.php?art_id=2584\&cat=1, accessed 14.07.07

http://www.buffalo.edu/news/8784, accessed 9.08.07.

http://www.avert.org/aids-zimbabwe.htm, accessed 08.12.07. 


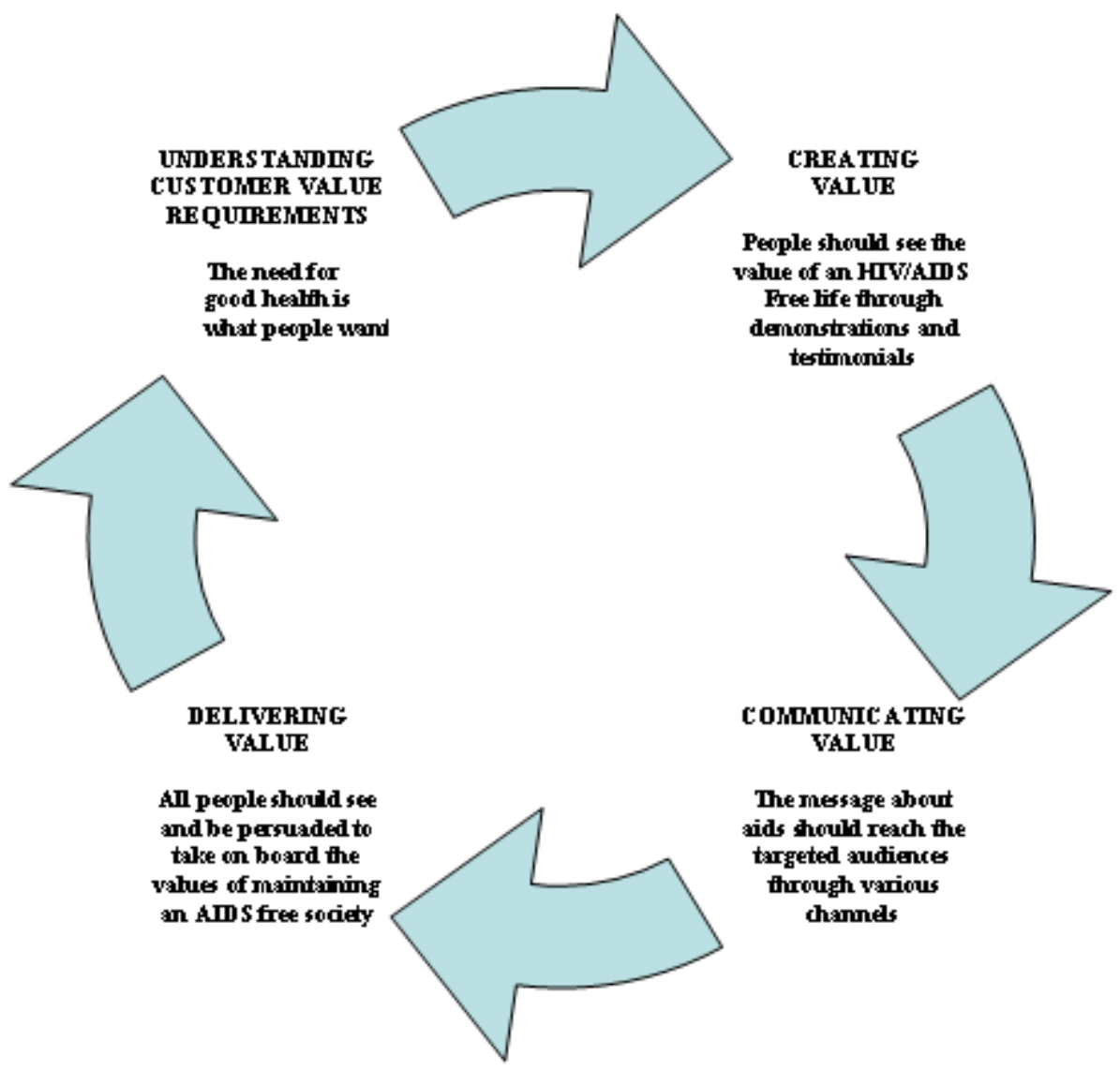

Source: Bathie and Sarkar (2002: p242)

Figure 1. Customer Focused Exchange

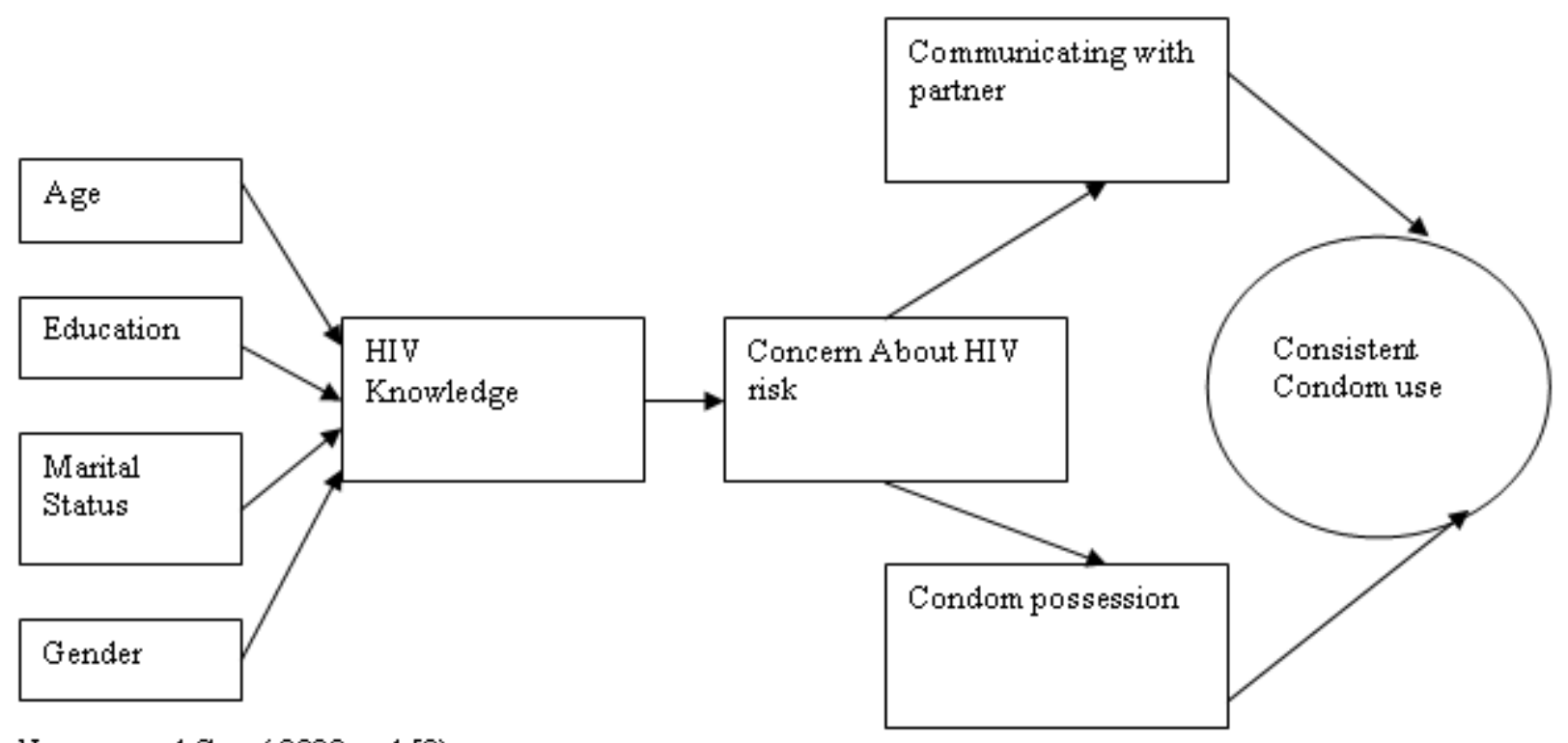

Norman and Carr (2003: p 150)

Figure 2. Explanatory Mode1 


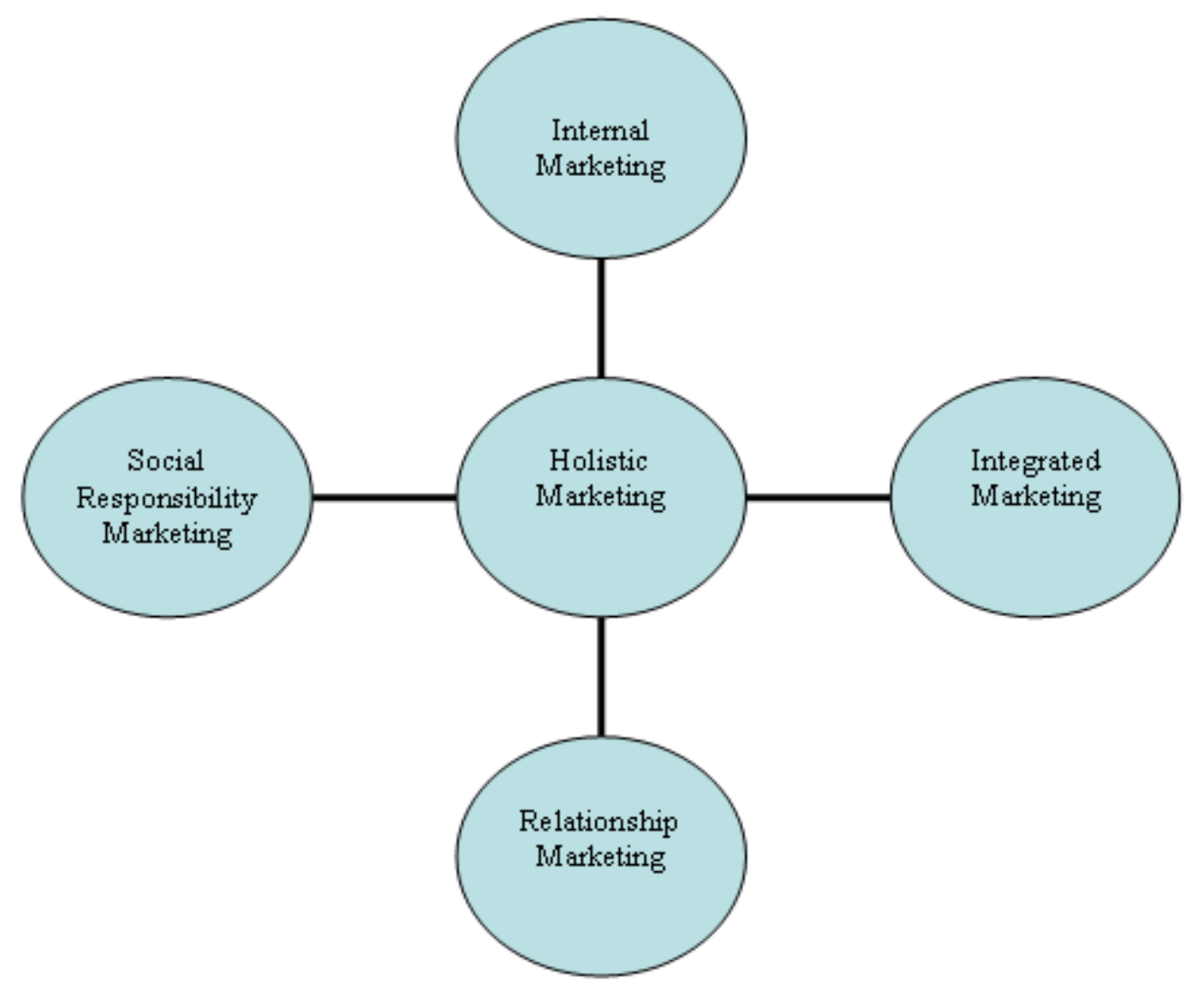

Source : Kotler and Keller (2006), Marketing Management, p18.

Figure 3. The Holistic Marketing Approach 